\title{
PENGEMBANGAN MEDIA KOMIK BERBASIS PENDIDIKAN KARAKTER PADA PEMBELAJARAN TEMATIK-INTEGRATIF KELAS IV SD
}

\section{DEVELOPING CHARACTER-BASED EDUCATION COMIC MEDIA ON INTEGRATIF-THEMATIC LEARNING FOR FOURTH GRADE}

\author{
Hengkang Bara Saputro, Soeharto \\ IKIP PGRI Wates Kulon Progo DI Yogyakarta, Universitas Negeri Yogyakarta \\ bara.uny@gmail.com, soeharto@uny.ac.id
}

\begin{abstract}
Abstrak
Penelitian ini bertujuan untuk menghasilkan media komik berbasis pendidikan karakter, mengetahui kelayakan media komik berbasis karakter, dan mengetahui keefektifan media komik berbasis karakter terhadap pengembangan karakter siswa kelas IV SD. Penelitian ini merupakan penelitian pengembangan, yang terdiri dari: (1) penelitian dan pengumpulan data, (2) perencanaan, (3) pengembangan draft produk, (4) validasi ahli, (5) revisi berdasarkan ahli, (6) uji coba terbatas, (7) penyempurnaan produk hasil uji coba terbatas, (8) uji coba lapangan, (9) penyempurnaan produk akhir, dan (10) diseminasi produk. Subjek coba pada penelitian ini adalah siswa kelas IV SDN Pangen Gudang Purworejo yang berjumlah 35 siswa dengan rincian: 6 siswa untuk uji coba terbatas dan 29 siswa untuk uji coba lapangan. Hasil penelitian menunjukkan bahwa: (1) telah dihasilkan media komik berbasis pendidikan karakter pada pembelajaran tematik-integratif, (2) media komik yang dikembangkan ditinjau dari variabel kualitas aspek media dan aspek materi menurut ahli, menurut guru, dan hasil respon siswa berkategori sangat baik, (3) pembelajaran dengan media komik yang dikembangkan efektif meningkatkan nilai karakter siswa. Peningkatan karakter disiplin siswa masuk dalam kategori sedang dengan nilai gain score sebesar 0,62 dan peningkatan karakter tanggung jawab siswa masuk dalam kategori sedang dengan nilai gain score sebesar 0,66.
\end{abstract}

Kata Kunci: pengembangan, media komik, pendidikan karakter.

\begin{abstract}
The objectives of this research are to produce character-based education comic media, determine the feasibility of character-based education comic media, and determine the effectiveness of character-based education comic media to character development of fourth grade students of SD. This research is a development, which consists of: (1) research and data collection, (2) planning , (3) development of a draft product, (4) validation of experts, (5) revisions based on expert, (6) limited testing, (7) improvement of product test results is limited, (8) the trial court, (9) the improvement of the final product, and (10) product dissemination. The subject of the study is fourth grade students of SDN Pangen Gudang Purworejo. There are 35 students consiting of 6 students for preliminary field testing, and the 29 students for main field testing. The result of the study shows: (1) character-based education comic media on integrative-thematic learning has been produced, (2) the developed comic media in terms of media aspect and material aspect quality according to experts, teachers, and student's responses are very good, (3) learning using comic media improves students' character value effectively. The improvement of students' discipline character is in medium category with 0.62 gain score and improvement of students' responsibility character is in medium category with 0.66 gain score.
\end{abstract}

Key words: research and development, comic, character education. 


\section{Pendahuluan}

Pendidikan adalah usaha sadar yang dilakukan oleh keluarga, masyarakat, dan pemerintah melalui kegiatan bimbingan, pengajaran, dan atau latihan, yang berlangsung di sekolah dan luar sekolah untuk mempersiapkan siswa agar dapat memainkan peranannya secara tepat dalam berbagai lingkungan hidup (Rohman, 2009, p.9). Pendidikan membuat manusia berusaha mengembangkan potensi yang ada dalam diri untuk mampu menghadapi setiap perubahan yang terjadi dalam kehidupan.

Pendidikan merupakan masalah yang kompleks, mulai dari jenjang pendidikan dasar, pendidikan menengah, sampai pada jenjang pendidikan tinggi. Sesuai dengan UU Sisdiknas Pasal 17 Tahun 2003 Butir 1 dan 2, dinyatakan bahwa "pendidikan dasar merupakan jenjang yang melandasi jenjang pendidikan menengah. Pendidikan dasar berbentuk Sekolah Dasar (SD) dan Madrasah Ibtidaiyah (MI) atau bentuk lain yang sederajat serta Sekolah Menengah Pertama (SMP) dan Madrasah Tsanawiyah (MTs) atau bentuk lain yang sederajat. Dikarenakan pendidikan dasar adalah jenjang yang melandasi untuk melanjutkan ke jenjang selanjutnya, maka peran pendidikan dasar sangatlah krusial dalam khasanah pendidikan manusia. Pendidikan dasar memiliki posisi strategis dalam rangka menanamkan nilai-nilai moral guna membangun generasi yang berkualitas unggul, tangguh, dan memiliki karakter yang kuat".

Pendidikan karakter penting untuk diimplementasikan di semua jenjang pendidikan, mulai dari sekolah dasar hingga perguruan tinggi. Secara umum, pendidikan karakter sesungguhnya dibutuhkan semenjak anak usia dini. Karakter seseorang apabila telah terbentuk sejak usia dini, maka ketika dewasa tidak akan mudah berubah meskipun banyak pengaruh yang datang (Azzet, 2011, p.15). Adanya pendidikan karakter semenjak usia dini, diharapkan mampu mengatasi persoalan mendasar dalam dunia pendidikan yang akhir-akhir ini sering menjadi keprihatinan bersama. Pendidikan karakter di Indonesia dirasakan amat perlu pengembangannya. Hal ini bila mengingat makin meningkatnya tawuran antar pelajar serta bentuk-bentuk kenakalan remaja lainnya terutama di kota-kota besar, seperti pemerasan, kekerasan (bullying), kecenderungan dominasi senior terhadap junior, fenomena suporter anarkis, penggunaan narkoba, dan lain-lain. Bahkan yang paling memprihatinkan keinginan untuk mengembangkan sifat jujur pada anak-anak melalui kantin kejujuran di sejumlah sekolah, banyak mengalami kegagalan karena belum bangkitnya sikap jujur, disiplin, dan tanggung jawab. Samani (2013, p. 5) memaparkan bahwa dalam dunia pendidikan kasus bertindak curang (cheating) baik berupa tindakan mencontek pekerjaan teman maupun mencontek dari buku pelajaran seolah-olah merupakan kejadian sehari-hari. Hal yang memprihatinkan juga terjadi di kalangan mahasiswa seperti melakukan kegiatan mencontek dan plagiarisme (plagiat) pada sejumlah mahasiswa tingkat akhir mulai dari mahaiswa tingkat sarjana bahkan sampai mahasiswa program doktor, juga melakukan hal yang serupa.

Kompas pada edisi 3 Juli 2013 mengungkapkan terjadinya kemerosotan moral yang ekstrem di kalangan remaja Indonesia, khusunya di kota-kota besar. Kemerosotan moral secara ekstrem di kalangan remaja tersebut ditandai dengan maraknya tindakan kekerasan yang mengakibatkan hilangnya nyawa orang lain (pembunuhan) oleh remaja. Beberapa kasus pembunuhan dilakukan oleh anak di bawah umur, seperti kasus pembunuhan yang dilakukan oleh anak berusia 8 tahun terhadap anak yang berusia 6 tahun di Bekasi pada bulan April 2013.

Berdasarkan ulasan tersebut, kita meyakini bahwa pendidikan merupakan garda terdepan pembentukan karakter bangsa. Pembentukan karakter bangsa melalui pendidikan dapat dilakukan dengan pengintegrasian nilai-nilai karakter dalam mata pelajaran yang diajarkan di sekolah. Hal ini sejalan dengan pendapat Kesuma, Trianta, \& Permana (2012, p. 5) yang memaparkan bahwa pendidikan karakter merupakan pendidikan yang terintegrasi dengan pembelajaran yang terjadi pada semua mata pelajaran, diarahkan pada penguatan dan pengembangan perilaku anak secara utuh, serta penguatan atau pengembangan perilaku yang didasari oleh nilai yang dirujuk sekolah. Pengintegrasian nilai-nilai karakter menjadi sangat penting demi kesiapan siswa dalam menghadapi setiap permasalahan dan tahapan dalam kehidupannya. Melalui pendidikan diharapkan dapat menghasilkan manusia yang berkualitas dan berkembang secara utuh sehingga dapat berperan aktif dalam pembangunan bangsa.

Pendidikan karakter begitu penting bagi pembentukan karakter yang kuat. Karakter yang kuat tidak akan terbentuk jika dalam proses pembelajaran hanya memfokuskan pada kegiat- 
an yang menekankan pada aspek kognitif saja. Hal ini sesuai dengan pendapat yang diungkapkan oleh Saptono (2011, p. 16) yang menyatakan bahwa pendidikan karakter sangat penting, karakter lebih tinggi nilainya daripada intelektualitas. Kehidupan kita bergantung pada karakter kita, karakter membuat orang mampu bertahan, memiliki stamina berjuang, dan sanggup mengatasi ketidak beruntungan secara bermakna.

Melihat nilai strategis pendidikan, pemerintah melalui Departemen Pendidikan Nasional (Depdiknas) terus menerus melakukan berbagai perubahan dan pembaharuan sistem pendidikan dengan tujuan agar generasi bangsa Indonesia menjadi bangsa yang cerdas sekaligus berkarakter. Salah satu upaya pemerintah dalam melakukan berbagai perubahan dan pembaharuan dalam sistem pendidikan nasional di Indonesia adalah dengan melakukan perubahan kurikulum.

Pemerintah melakukan perubahan dari Kurikulum Tingkat Satuan Pendidikan (KTSP) menjadi Kurikulum 2013. Implementasi kurikulum 2013 dimulai hari Senin, 15 Juli 2013 pada 6.326 sekolah di jenjang SD, SMP, dan SMA/SMK. Kurikulum baru tersebut diterapkan di 10\% SD, 20\% SMP berakreditasi A, serta seluruh SMA/SMK di tanah air (Kompas edisi Senin, 15 Juli 2013). Kurikulum 2013 memandang bahwa pengembangan sikap menjadi salah satu hal penting untuk ditekankan karena siswa akan menjadi generasi penerus bangsa yang diharapkan memiliki pribadi-pribadi yang berkarakter. Penerapan Kurikulum 2013 ini diwujudkan dalam model pembelajaran tematikintegratif. Pembelajaran tematik-integratif merupakan pendekatan pembelajaran yang mengintegrasikan berbagai kompetensi dari berbagai mata pelajaran ke dalam berbagai tema (Kemendikbud, 2013, p. 137).

Struktur Kurikulum 2013 dengan model pembelajaran tematik-integratif. Hal itu sesuai dengan yang tercantum dalam Dokumen Kurikulum 2013 (Kemdikbud, 2012, pp. 13-14), yaitu: (1) untuk SD bersifat tematik-integratif: IPA dan IPS akan diintegrasikan dengan semua mata pelajaran (IPA akan menjadi materi pembahasan pelajaran Bahasa Indonesia dan matematika, IPS akan menjadi pembahasan materi pelajaran Bahasa Indonesia dan PKn) dan (2) kompetensi yang ingin dicapai adalah kompetensi yang berimbang antara sikap, keterampilan, dan pengetahuan. Berdasarkan pada uraian tersebut, model pembelajaran tematik-integratif bertujuan mengembangkan potensi setiap siswa agar menjadi manusia yang utuh, tidak hanya cerdas secara intelektual tetapi juga cerdas secara emosional maupun spiritual.

Perubahan kurikulum, akan berdampak pada perubahan sistem pembelajaran, tidak terkecuali sistem pembelajaran di jenjang SD. Kebijakan pemerintah dalam melakukan perubahan dari KTSP menjadi Kurikulum 2013 bukan berarti tanpa menemui kendala, baik pada tahap persiapan maupun pada tahap implementasinya. Kompas edisi 12 Juli 2013 mengungkapkan bahwa guru-guru masih ragu pada implementasi Kurikulum 2013 yang akan dilaksanakan mulai 15 Juli 2013. Hal tersebut dikarenakan masa pelatihan guru-guru yang terlalu singkat, yakni hanya lima hari. Selain itu tidak mudah mengubah paradigma guru dari metode konvensional seperti ceramah di depan kelas menjadi fasilitator dan motivator bagi siswa dalam waktu yang singkat.

Beberapa kendala juga masih dijumpai pada tahap implementasi Kurikulum 2013. Seperti dikutip dari harian Kompas pada edisi 16 Juli 2013, dipaparkan bahwa implementasi Kurikulum 2013 di sejumlah daerah masih bermasalah. Buku-buku pelajaran belum terdistribusikan dengan baik, guru-guru merasa pelatihan belum optimal, dan pemerintah kabupaten/ kota mengambil kebijakan sendiri-sendiri.

Berdasarkan pemaparan tersebut, kita ketahui bahwa masih ditemukan beberapa kendala dalam persiapan maupun implementasi Kurikulum 2013. Masih kurangnya pemahaman guru dalam mengimplementasikan kurikulum baru ke dalam pembelajaran di kelas. Hal ini dikarenakan waktu pelatihan dan sosialisasi yang dianggap terlalu singkat. Banyaknya sumber belajar yang akan dirubah dan digantikan dengan sumber belajar yang baru. Selain itu, distribusi bahan ajar yang belum optimal dan belum merata ke seluruh sekolah yang di tunjuk oleh pemerintah untuk menerapkan kurikulum 2013. Oleh karena itu, guru sebagai pendidik dituntut untuk dapat menyikapi masa transisi perubahan kurikulum tersebut dengan berinovasi melalui pengembangan kreativitas dalam pembelajaran. Salah satu hal yang dapat dilakukan guru adalah dengan cara mengembangkan media pembelajaran yang efektif, menarik, sesuai dengan karakteristik siswa.

Berkenaan dengan fungsi media, Orey, M., McClendon, V. J., \& Branch, R. M. (2006, p. vii) mengemukakan bahwa "media serve as delivery systems for educational communica- 
tions." Artinya bahwa media berfungsi sebagai sistem pengiriman untuk komunikasi pendidikan. Media pembelajaran dapat dijadikan alternatif sumber belajar oleh guru apabila pada kenyataannya pemberian pengalaman belajar secara langsung sulit untuk dilakukan. Banyak ahli telah mengkaji peranan media dalam proses pembelajaran. Sudjana \& Rivai (2010, p. 2) menyatakan bahwa media pembelajaran dapat digunakan untuk meningkatkan proses belajar siswa, yang pada gilirannya diharapkan akan dapat mempertinggi hasil belajar yang dicapai. Hal tersebut juga dikuatkan oleh pendapat dari Newby et al. (2000, p. 100) yang menyatakan "The purpose of instructional media is to facilitate communication and enhance learning".

Sejalan dengan itu tampak bahwa media pembelajaran merupakan sarana yang digunakan sebagai perantara dalam proses pembelajaran. Media pembelajaran yang efektif tidak ditentukan dari mahal atau murahnya maupun frekuensi penggunaan media tersebut, tetapi tergantung pada kesesuaian antara karakteristik media dengan materi yang disampaikan, serta sesuai dengan tahap perkembangan anak termasuk di dalamnya adalah komik.

Komik sebagai bagian dari media cetak, dapat dikembangkan sebagai alternatif media pembelajaran. Berkenaan dengan peranan media komik, Maharsi (2011, p. 10) memberikan pendapat bahwa komik mempunyai peranan yang besar untuk memberikan informasi yang mendidik, menghibur, sekaligus mempegaruhi seperti hakekat fungsi dari komunikasi. Daryanto (2013, p. 128) memaparkan mengenai kelebihan komik sebagai media pemebelajaran, yakni komik mengandung unsur visual dan cerita yang kuat. Ekspresi yang divisualisasikan membuat pembaca terlibat secara emosional sehingga membuat pembaca untuk terus membacanya hingga selesai. Dengan demikian, di samping meningkatkan minat baca siswa, media komik sangat efektif dalam menransfer nilai-nilai karakter melalui penokohan dalam cerita komik tersebut.

Realitanya, komik memang merupakan salah satu bacaan yang paling diminati bukan saja oleh pembaca anak-anak, tetapi juga oleh sebagian orang dewasa. Bacaan komik mampu memotivasi anak dalam membaca bahkan dapat memberikan inspirasi imajinasi anak sesuai dengan masa perkembangan anak. Bacaan komik hadir dengan keunikannya sendiri, tampil dengan deretan gambar, panel-panel dengan sedikit tulisan tangan yang ditempatkan dalam balon-balon teks. Gambar-gambar komik itu sendiri pada umumnya sudah "berbicara", dan dibuat menjadi deretan gambar yang menampilkan suatu alur cerita.

Menurut Sudjana \& Rivai (2010, p. 68), peran pokok dari media komik adalah kemampuannya dalam menciptakan minat para siswa dalam pembelajaran. Penggunaan komik dalam pembelajaran sebaiknya dipadukan dengan metode mengajar, sehingga komik akan dapat menjadi media pembelajaran yang efektif. Hal tersebut juga diperkuat oleh pendapat Faizah (2009, p. 254) yang menyatakan bahwa "siswa pada sekolah dasar memiliki ketertarikan yang tinggi terhadap gambar visual dan juga terhadap cerita." Melalui penokohan dalam komik, nilainilai karakter dapat disampaikan kepada para siswa. Adanya media komik diharapkan akan mempermudah proses belajar mengajar, khususnya dalam merealisasi konsep-konsep pelajaran yang bersifat abstrak. Dalam hal inilah komik berperan besar dalam menyajikan konsep-konsep abstrak tersebut ke dalam contoh yang lebih konkrit dalam kehidupan sehari-hari yang bermuatan nilai-nilai karakter.

Pembelajaran dengan menggunakan media komik, sudah banyak diterapkan oleh beberapa negara maju seperti Jepang. Beberapa buku pelajaran sekolah di Jepang ada yang didesain dalam format komik. Bahkan untuk mendukung keberadaan kartun dan komik di Negara Jepang, telah didirikan fakultas khusus untuk memperdalam bidang kartun dan komik di Universitas Seika, Kyoto (Sasongko, 2013, p. 51).

Buku pelajaran dalam bentuk komik merupakan sarana pendidikan efektif untuk membangkitkan motivasi membaca dan belajar bagi siswa. Hal ini senada dengan pendapat yang dikemukakan oleh Sudjana \& Rivai (2010, p. 68) bahwa media komik dapat berfungsi sebagai jembatan dalam menumbuhkan minat baca bagi siswa.

Proses pembelajaran pada prinsipnya merupakan proses komunikasi. Masalahnya adalah bagaimana agar proses komunikasi itu berjalan dengan efektif, sehingga pesan yang ingin disampaikan dapat diterima siswa secara utuh. Untuk kepentingan tersebut, seorang guru dapat menggunakan variasi dalam penggunaan media pembelajaran tersebut.

Media pembelajaran yang dikemas dalam bentuk komik dapat digunakan sebagai salah satu variasi media pembelajaran. Media komik ini memiliki potensi untuk lebih disukai siswa, 
hal ini dikarenakan gambar dalam komik dapat menghidupkan deretan teks tertulis yang menyertainya. Dengan gambar, penjelasan panjang lebar dan rumit dari teks atau topik pembelajaran yang dibaca dapat menjadi lebih mudah dipahami dan diingat oleh siswa. Bahkan siswa dapat memahami dan membayangkan lebih dahulu apa yang sebenarnya menjadi inti dari topik pelajaran yang ia baca melalui gambar yang ada.

Kelebihan lain dari sebuah komik adalah penyajiannya mengandung alur cerita. Sudah sejak lama cerita menjadi alat untuk meyampaikan pesan dalam masyarakat. Hal ini terlihat dari banyaknya masyarakat yang menciptakan cerita dongeng ataupun legenda untuk meyampaikan sebuah nilai maupun adat istiadat yang berlaku di masyarakat. Cerita yang menarik dan mempunyai alur yang kuat mampu memberikan struktur mitologi yang dapat mengubah jalan hidup anak (Humphrey, 2005, p.xix). Oleh karenanya, materi pembelajaran yang dikemas dalam alur cerita yang jelas akan membuat materi tersebut bertahan lebih lama dalam ingatan siswa. Dengan demikian, selain dapat meningkatkan motivasi belajar siswa karena penyajiannya yang menarik, komik juga berpotensi untuk meningkatkan pemahaman siswa.

Berdasarkan uraian tersebut dapat diketahui bahwa komik mempunyai potensi besar sebagai media pembelajaran. Perpaduan gambar dan teks dapat meningkatkan pemahaman siswa akan konsep yang dipelajari, sementara karakter tokoh dalam komik dapat digunakan sebagai teladan untuk menyampaikan pesan nilai-nilai karakter. Oleh karena itu, dengan adanya media komik berbasis pendidikan karakter untuk siswa kelas IV SD diharapkan pembelajaran tematikintegratif yang diterapkan menjadi lebih menyenangkan dan bermakna. Melalui bimbingan guru, komik dapat berfungsi sebagai jembatan untuk menumbuhkan minat baca sesuai dengan taraf berpikir siswa, yang akhirnya dapat pula meningkatkan pemahaman siswa akan materi yang diajarkan. Media komik ini juga diharapkan dapat menjadi alat untuk pendidikan karakter.

Penyajian komik sebagai media pembelajaran harus sesuai dengan karakteristik komik dan karaktersitik media pembelajaran. Sebagai media pembelajaran, komik termasuk dalam kelompok media grafis berbasis cetak. Kedudukan komik dapat menggantikan buku teks pelajaran maupun sebagai pendamping buku teks pelajaran dalam proses pembelajaran. Oleh karenanya penyusunan media pembelajaran komik harus mencakup aspek-aspek penyusunan komik dan aspek-aspek penyusunan buku teks pelajaran. Aspek-aspek yang harus dipenuhi dalam penyusunan buku teks pelajaran menurut Depdiknas (2008, p.28) adalah sebagai berikut: (1) Komponen kelayakan isi, yang merupakan kesesuaian isi buku dengan Standar Kompetensi (SK) dan Kompetensi Dasar (KD); (2) Komponen kebahasaan, yaitu kesesuaian penggunaan bahasa dengan perkembangan siswa; (3) Komponen penyajian, yang merupakan kesesuaian penyajian buku dengan sistematika penyajian sehingga buku mudah dipahami siswa; (4) Komponen kegrafikaan, yang meliputi kesesuaian gambar dengan isi, tata letak gambar, warna, huruf, kekuatan fisik buku, dan kulaitas cetakan.

Selama ini, paradigma dan persepsi umum yang melekat di kalangan guru dalam menyusun media pembelajaran adalah bahwa hal tersebut sulit dan melelahkan. Proses penyusunan media membutuhkan waktu, tenaga, dan biaya yang tidak sedikit, serta terkadang harus mengorbankan waktu senggang untuk duduk di depan komputer atau meja kerja. Persepsi ini keliru dan harus diluruskan demi terciptanya proses pembelajaran yang berkualitas.

Realitanya di lapangan, masih banyak guru yang kurang mengembangkan kreativitas mereka untuk merencanakan, menyusun, dan mengembangkan media pembelajaran yang inovatif dan menarik bagi siswa. Banyak pendidik yang masih menggunakan media pembelajaran yang konvensional, misalnya papan tulis dan whiteboard, atau media pembelajaran yang sifatnya instan, tinggal beli dan langsung pakai seperti media gambar dinding, poster, dan peta. Hal ini berimbas pada menurunnya kreativitas guru serta berpengaruh pada minat siswa dalam pembelajaran. Sangat mungkin bahwa media pembelajaran yang mereka pakai tersebut tidak kontekstual, kurang menarik, terkesan monoton, dan tidak sesuai dengan kebutuhan siswa.

Berdasarkan hasil wawancara pada tanggal 4 Oktober 2013 dengan guru kelas IV SD Negeri Cangkrep Kidul, Kecamatan Cangkrep, Kabupaten Purworejo, diperoleh informasi bahwa: (1) SD Negeri Cangkrep Kidul telah menerapkan pembelajaran tematik-integratif; (2) guru mengungkapkan bahwa persiapan pelaksanaan Kurikulum 2013 terlalu singkat; (3) pelatihan dan sosialisasi diselenggarakan dalam waktu yang cukup singkat yakni lima hari, sehingga pemahaman guru akan konsep dan teknis pelaksanaan pembelajaran dengan Kuri- 
kulum 2013 belum komprehensif; dan (4) buku siswa dan buku pegangan guru yang diterima oleh SDN Cangkrep Kidul jumlahnya memadai.

Dalam wawancara yang dilakukan dengan guru kelas IV SDN Cangkrep Kidul pada tanggal 5 Oktober 2013, guru mengakui masih mengalami kesulitan dalam menerapkan pembelajaran dengan Kurikulum 2013. Hal tersebut terkait dengan paradigma guru yang harus berubah dari mengajar berbasis mata pelajaran menjadi berbasis tema. Di samping itu, guru mengungkapkan belum tersedianya media pembelajaran yang mampu mengaktifkan siswa terkait dengan penilain otentik. Media pembelajaran yang ada meliputi media gambar yang ditempel di dinding kelas (gambar pahlawan nasional dan gambar anatomi tubuh manusia), peta Indonesia, papan tulis, whiteboard, dan papan pajangan karya siswa.

Kondisi yang serupa juga ditemui pada saat peneliti melakukan observasi lapangan dan wawancara dengan guru kelas IV SD Negeri Pangen Gudang, Kecamatan Purworejo, Kabupaten Purworejo. SD tersebut ditunjuk oleh Dinas Pendidikan Kabupaten Purworejo untuk menerapkan Kurikulum 2013 terhitung mulai Juli 2013. Berdasarkan hasil wawancara yang dilakukan pada tanggal 9-10 Oktober 2013, diperoleh informasi yang sama yakni guru masih mengalami kendala dalam implementasi pembelajaran tematik-integratif di kelas. Kegiatan pembelajaran yang dilakukan, hanya menggunakan buku teks untuk siswa dan buku pegangan guru yang didistribusikan dari pemerintah. Menurut guru, sumber belajar yang lain seperti LKS belum digunakan karena belum tersedia LKS tematik-integratif yang dipasok dari percetakan seperti tahun ajaran sebelumnya.

Terkait dengan penggunaan media, guru mengakui bahwa di dalam pembelajaran belum pernah menggunakan media pembelajaran yang tergolong inovatif. SDN Pangen Gudang telah memiliki LCD proyektor, namun guru belum memanfaatkannya secara optimal karena masih terkendala dalam penggunaan dan penyusunan materi pembelajaran berbasis komputer. Hanya beberapa guru yang mampu mengoperasikan komputer dengan baik. Media pembelajaran yang dimiliki SDN Pangen Gudang tidak jauh berbeda dengan SDN Cangkrep Kidul. Guru mengakui, bahwa keberadaan media pembelajaran sangat penting untuk menumbuhkan minat siswa dan mengefektifkan proses pembelajaran. Banyak faktor yang diungkapkan oleh para guru di kedua SD tersebut terkait kendala dalam pengembangan media, antara lain faktor kemauan, waktu, biaya, dan kreativitas.

Bertolak dari hasil observasi dan wawancara yang telah dilakukan, hal tersebut merupakan permasalahan yang serius dan seharusnya segera dicarikan solusi. Salah satunya, para guru perlu menumbuhkan kemauan dan kreativitasnya, agar mampu mengembangkan media pembelajaran yang inovatif dan menarik sesuai dengan karakteristik siswa, karena dapat meningkatkan kualitas pembelajaran.

Berdasarkan pemaparan tersebut, penelitian ini layak dilakukan untuk mengembangkan media pembelajaran berupa media komik tematik-integratif berbasis pendidikan karakter pada siswa kelas IV SDN Pangen Gudang Purworejo.

\section{Metode}

\section{Model Pengembangan}

Penelitian ini menggunakan model penelitian research and development yang dikembangkan oleh Borg and Gall (1983, p.775). Tahap-tahap penelitian dan pengembangan yang dikembangkan oleh Borg and Gall adalah: (1) research and information collecting (studi pendahuluan), (2) planning (perencanaan), (3) develop preliminary form of product (pengembangan draft), (4) preliminary field testing (uji coba lapangan awal /uji coba terbatas), (5) main produc revision (revisi produk pertama), (6) main field testing (uji coba akhir/uji coba lapangan), (7) operational product revision (revisi produk operasional), (8) operasional field testing (uji coba lapangan operasional), (9) final product revision (revisi produk final), dan (10) desemination and implementation (penyebaran dan pemakaian).

\section{Desain Uji Coba}

Uji coba produk hasil pengembangan yang berupa media komik pembelajaran dalam penelitian ini terdiri dari beberapa tahapan yaitu: (a) validasi produk oleh ahli media, ahli materi, dan guru SD (b) revisi I, (c) uji coba terbatas, (d) revisi II, (e) uji coba lapangan, (f) revisi III, (g) produk akhir.

\section{Subjek Uji Coba}

Subjek uji coba adalah siswa kelas IV SDN Pangen Gudang Purworejo. Subjek uji coba terbatas terdiri atas 6 orang siswa. Subjek uji coba lapangan terdiri atas 29 orang siswa yang belum terlibat dalam uji coba terbatas. 
Jenis Data

Data penelitian ini berupa data validasi ahli media dan materi mengenai kelayakan produk yang dikembangkan berupa media komik, data angket respon siswa terhadap penggunaan media komik, data keterlaksanaan pembelajaran oleh guru dan siswa, data angket karakter disiplin dan tanggung jawab siswa, serta data observasi karakter disiplin dan tanggung jawab siswa.

\section{Instrumen Pengumpulan Data}

Instrumen penelitian dalam penelitian ini dibagi menjadi dua bagian. Pertama, instrumen untuk mengukur kevalidan media yang meliputi lembar: (1) lembar validasi ahli materi, (2) lembar validasi ahli media, (3) lembar penilaian untuk guru. Kedua, instrumen untuk mengukur keefektifan media yang meliputi lembar: (1) angket respon siswa terhadap penggunaan media komik, (2) angket karakter disiplin dan tanggung jawab siswa, (3) observasi karakter disiplin dan tanggung jawab siswa, dan (4) observasi keterlakasanaan pembelajaran guru dan siswa.

\section{Teknik Analisis Data}

Dalam penelitian ini data dianalisa untuk mendapatkan perangkat pembelajaran berupa media yang valid dan efektif. Apabila syarat tersebut terpenuhi, produk media komik pembelajaran yang dikembangkan layak untuk digunakan.

Untuk mengetahui kualitas media komik hasil pengembangan baik dari aspek media maupun aspek materi, serta untuk mengetahui respon siswa terhadap media komik dari data yang mula-mula berupa skor, diubah menjadi data kualitatif (data interval) dengan skala empat. Adapun acuan pengubahan skor menjadi skala empat tersebut menurut Juknis Penyusunan Perangkat Penilaian Afektif di SMA (2010, p. 60) dapat dilihat pada tabel 1 .

Tabel 1. Konversi Skor Aktual Menjadi Nilai Skala Empat

\begin{tabular}{ccc}
\hline Rentang Skor & Nilai & Kategori \\
\hline $\mathrm{Mi}+1,5 \mathrm{SD} i \leq \mathrm{X} \leq \mathrm{Mi}+3 \mathrm{SD} i$ & $\mathrm{~A}$ & Sangat Baik \\
$\mathrm{Mi}+0 \mathrm{SD} i \leq \mathrm{X}<\mathrm{Mi}+1,5 \mathrm{SD} i$ & $\mathrm{~B}$ & Baik \\
$\mathrm{Mi}-1,5 \mathrm{SD} i \leq \mathrm{X}<\mathrm{Mi}+0 \mathrm{SD} i$ & $\mathrm{C}$ & Cukup Baik \\
$\mathrm{Mi}-3 \mathrm{SD} i \leq \mathrm{X}<\mathrm{Mi}-1,5 \mathrm{SD} i$ & $\mathrm{D}$ & Kurang Baik \\
\hline
\end{tabular}

\section{Keterangan:}

$\mathrm{X}=$ skor actual (skor yang dicapai)

$\mathrm{Mi}=1 / 2$ (skor maksimal + skor minimal)

$\mathrm{SD}_{i}=1 / 6$ (skor maksimal - skor minimal)

Skor maksimal $=$ jumlah butir criteria $\mathrm{x}$ skor maksimum

Skor minimum $=$ jumlah butir criteria $\mathrm{x}$ skor minimum

\section{Hasil Penelitian dan Pembahasan}

Deskripsi Pengembangan

Pada awal pengembangan dilakukan tahap pendefinisian yang meliputi kegiatan: analisis pustaka dan lapangan. Setelah tahap pendefinisian selesai kemudian dilanjutkan dengan tahap pengembangan yang meliputi kegiatan pembuatan draf media komik, mengumpulkan semua materi yang dibutuhkan dalam pembuatan media komik, pembuatan produk, melakukan review untuk mendapatkan validasi kepada ahli media, ahli materi, dan guru SD, dilanjutkan dengan analisis dan revisi produk berdasarkan komentar dan saran dari ahli media, materi, dan guru SD tersebut. Proses revisi pertama setelah selesai, kemudian mengemas produk awal media komik sebagai media pembelajaran tematik-integratif. Draft produk yang telah selesai dikembangkan kemudian diujico- bakan secara terbatas dan uji coba lapangan (di sekolah).

\section{Deskripsi Uji coba Produk}

Uji coba pada tahap validasi produk oleh ahli media, ahli materi, dan guru SD dilakukan untuk memperoleh data kevalidan media dari aspek materi dan aspek media. Syarat kevalidan komponen adalah dengan minimal diperolehnya nilai skor rata-rata berkategori baik. Apabila kategori telah mencapai baik, maka komponen sudah dinyatakan layak.

Hasil akhir validasi dan uji kelayakan tercapai rata-rata berkategori sangat baik sehingga media komik yang dikembangkan dinilai valid dan layak untuk diuji cobakan lebih lanjut. Saran dari ahli, antara lain (1) memperbaiki ejaan yang ada dalam percakapan media komik, (2) pemilihan warna agar disesuaikan karakter siswa, dan (3) memperbaiki bagian posisi gam- 
bar agar lebih disesuaikan dengan pesan dari media yang dikembangkan. Perbaikan pada produk media komik dilakukan sesuai dengan saran dari ahli.

Data hasil validasi produk oleh ahli media dan ahli materi disajikan dalam tabel 2 dan tabel 3, sedangkan untuk hasil penilaian produk oleh guru SD disajikan dalam tabel 4 .

Tabel 2. Hasil Penilaian Kevalidan Media Komik oleh Ahli Media

\begin{tabular}{clrc}
\hline No & Aspek Penilaian & $\begin{array}{r}\text { Total } \\
\text { Skor }\end{array}$ & Kriteria \\
\hline 1 & Anatomi Komik & 27,00 & Sangat Baik \\
2 & Desain dan Warna & 14,00 & Sangat Baik \\
3 & Tampilan Menyeluruh & 25,00 & Sangat Baik \\
\hline
\end{tabular}

Tabel 3. Hasil Kelayakan Media Komik oleh Ahli Materi

\begin{tabular}{clcl}
\hline No & Aspek Penilaian & $\begin{array}{r}\text { Total } \\
\text { Skor }\end{array}$ & Kriteria \\
\hline 1 & Kelayakan Materi & 24,00 & Sangat Baik \\
2 & Keakuratan Materi & 14,00 & Sangat Baik \\
3 & Kemutakhiran Materi & 4,00 & Sangat Baik \\
4 & Kebahasaan & 19,00 & Sangat Baik \\
5 & Nilai Karakter & 8,00 & Sangat Baik \\
\hline
\end{tabular}

Tabel 4. Hasil Kelayakan Media Komik oleh guru SD

\begin{tabular}{clrc}
\hline No & Aspek Penilaian & $\begin{array}{r}\text { Total } \\
\text { Skor }\end{array}$ & Kriteria \\
\hline 1 & Anatomi Komik & 26,50 & Sangat Baik \\
2 & Desain dan Warna & 13,00 & Sangat Baik \\
3 & Tampilan Menyeluruh & 26,50 & Sangat Baik \\
4 & Kelayakan Materi & 21,50 & Sangat Baik \\
5 & Keakuratan Materi & 14,00 & Sangat Baik \\
6 & Kemutakhiran Materi & 3,50 & Sangat Baik \\
7 & Kebahasaan & 7,00 & Sangat Baik \\
8 & Nilai Karakter & 7,00 & Sangat Baik \\
\hline
\end{tabular}

Tahap selanjutnya adalah uji coba terbatas. Uji coba terbatas diberikan kepada 6 siswa kelas IV. Data yang diperoleh berupa data respon siswa terhadap penggunaan media komik selama proses pembelajaran. Analisis respon siswa termasuk dalam kategori sangat baik. Saran yang diperoleh dari uji terbatas yaitu penggunaan bahasa dalam percakapan komik dan pembenahan beberapa gambar yang blur. Data hasil respon siswa terhadap penggunaan komik dapat dilihat pada tabel 5.

Tabel 5 Data Hasil Respon Siswa terhadap Penggunaan Media Komik

\begin{tabular}{ccccc}
\hline \multirow{2}{*}{ No } & \multirow{2}{*}{ Aspek Respon } & \multicolumn{3}{c}{ Siswa } \\
\cline { 3 - 5 } & Media & Tinggi & Sedang & Rendah \\
\hline 1 & Isi/Materi & 17,5 & 16,5 & 17,5 \\
2 & Kebahasaan & 71,0 & 10,5 & 11,0 \\
3 & Karakter & 7,0 & 6,5 & 7,5 \\
4 & & 7,5 & 8 & 7 \\
\hline
\end{tabular}

Setelah dilakukan revisi sesuai masukan yang diperoleh pada uji coba terbatas, maka produk media komik selanjutnya diujicobakan pada uji coba lapangan. Uji coba lapangan dilakukan pada siswa kelas IV SDN Pangen Gudang Kabupaten Purworejo yang terdiri dari 29 siswa.

Dalam uji coba ini dilaksanakan pembelajaran dengan produk media komik hasil pengembangan dengan desain before-after. Uji coba lapangan dilaksanakan untuk mengetahui kelayakan media komik yang sebelumnya sudah diuji cobakan pada skala yang lebih kecil. Selain itu, juga bertujuan untuk mengetahui keefektifan penggunaan media komik.

Data yang diperoleh dari uji lapangan adalah data respon siswa, data observasi keterlaksanaan pembelajaran siswa dan guru oleh pengamat, data karakter siswa sebelum dan setelah pembelajaran dengan media komik (ang- ket awal-angket akhir), serta data observasi karakter siswa.

Dari data respon siswa rerata penilaian siswa mengenai pembelajaran dengan media komik berada pada kategori sangat baik. Data hasil respon siswa terhadap penggunaan komik pada uji coba lapangan dapat dilihat pada tabel 6.

Tabel 6. Data Respon Siswa terhadap Penggunaan Media Komik pada Uji Coba Lapangan

\begin{tabular}{cccc}
\hline No & Aspek Respon & Total Skor & Kategori \\
\hline 1 & Media Komik & 17,90 & SB \\
2 & Isi/Materi & 11,07 & SB \\
3 & Kebahasaan & 7,03 & SB \\
4 & Karakter & 6,86 & SB \\
\hline
\end{tabular}

Uji coba lapangan juga bertujuan untuk mengetahui efektifitas penggunaan media komik. Data efektifitas penggunaan media komik ini diperoleh dari hasil observasi keterlaksanaan 
pembelajaran siswa dan guru oleh pengamat serta nilai angket karakter sebelum dan sesudah penggunaan media komik.

Keterlaksanaan pembelajaran oleh guru selama penggunaan media komik dari hari pertama sampai dengan hari keenam menunjukkan persentase $80 \%, 80 \%, 85 \%, 95 \%, 100 \%$, dan $100 \%$. Hal ini menunjukkan bahwa guru sudah melaksanakan kegiatan pembelajaran sesuai dengan rencana pembelajaran yang sudah dibuat. Selain itu persentase tersebut dapat menujukkan bahwa pembelajaran dengan menggunakan media komik sudah mencapai target yang diharapkan. Hasil perhitungan observer pada uji coba lapangan ini mendapatkan prosentase keterlaksanaan pembelajaran pada siswa dari hari pertama hingga hari keenam adalah $75 \%, 85 \%$, $85 \%, 90 \%, 95 \%$, dan $100 \%$. Hal ini menunjukkan bahwa siswa sudah melaksanakan kegiatan pembelajaran sesuai dengan rencana pembelajaran yang sudah dibuat. Selain itu persentase tersebut juga menunjukkan bahwa pembelajaran menggunakan media komik sudah sesuai target yang diharapkan.

Uji coba lapangan juga untuk mengetahui efektivitas media komik dalam meningkatkan karakter disiplin dan tanggung jawab siswa.
Data pengembangan karakter siswa diperoleh melalui lembar angket yang diisi oleh siswa dan data hasil observasi oleh observer. Hasil angket siswa awal dan akhir terhadap karakter disiplin dapat dilihat pada tabel 7 , sedangkan untuk karakter tanggung jawab dapat dilihat pada tabel 8 .

Tabel 7. Data Angket Karakter Disiplin Uji Coba Lapangan

\begin{tabular}{|c|c|c|}
\hline Skor & Awal & Akhir \\
\hline Tertinggi & 87 & 98 \\
\hline Terendah & 58,33 & 76,67 \\
\hline Rata-rata & 71,15 & 89,02 \\
\hline Gain & \multicolumn{2}{|c|}{0,62} \\
\hline
\end{tabular}

Tabel 8. Data Angket Karakter Tanggung Jawab Uji Coba Lapangan

\begin{tabular}{cccc}
\hline Skor & Awal & Akhir \\
\hline Tertinggi & 86,67 & & 98,3 \\
Terendah & 58,33 & & 80 \\
Rata-rata & 71,61 & & 90,46 \\
Gain & & 0,66 & \\
\hline
\end{tabular}

Hasil observasi karakter disiplin dan tanggung jawab siswa selama uji coba lapangan dapat dilihat pada tabel 9.

Tabel 9. Data Observasi Karakter Uji Coba Lapangan

\begin{tabular}{cccccccc}
\hline \multirow{2}{*}{ No } & \multirow{2}{*}{ Nilai Karakter } & \multicolumn{7}{c}{ Pertemuan Ke- } \\
\cline { 3 - 8 } & Disiplin & I & II & III & IV & V & VI \\
\hline 1 & Tanggung Jawab & 51,03 & 49,66 & 57,24 & 65,98 & 74,71 & 81,15 \\
2 & Ty & 59,08 & 67,82 & 75,40 & 80,00 & 83,45 \\
\hline
\end{tabular}

Penentuan ketercapaian peningkatan karakter disiplin dan tanggung jawab pada uji coba lapangan ini didasarkan pada tabel 7 dan tabel 8, yaitu nilai yang dicapai oleh siswa melalui angket yang dibagikan sebelum uji coba penggunaan komik (awal) dan setelah uji coba penggunaan komik (akhir). Secara deskriptif peningkatan ini juga dapat dilihat melalui rata-rata skor yang dicapai oleh 29 siswa pada angket awal dan akhir, yang secara visual tampak pada gambar 1 .

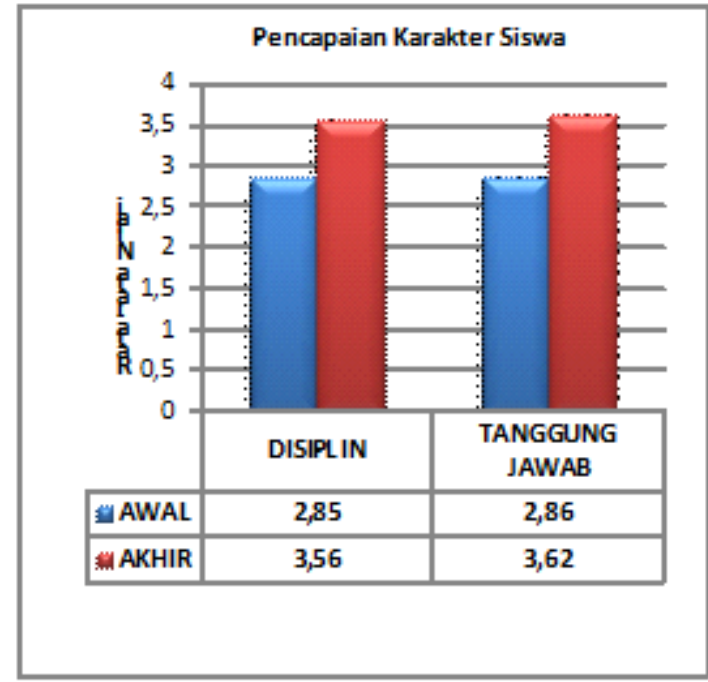

Gambar 1. Diagram Pencapaian Karakter Disiplin dan Tanggung Jawab Siswa pada Uji Coba Lapangan 
Ketercapaian peningkatan nilai karakter disiplin seperti pada tabel 7 kemudian dianalisis menggunakan teknik gain. Analisis tersebut bertujuan untuk mengetahui peningkatan karakter siswa antara sebelum dan sesudah mengikuti pembelajaran menggunakan media komik berbasis karakter.

Hasil analisis angket karakter disiplin siswa didapatkan gain score, $\langle\mathrm{g}\rangle=0,62$. Menurut Hake (1998, p. 65) peningkatan karakter disiplin tersebut termasuk dalam kategori "Sedang". Ketercapaian peningkatan karakter tanggung jawab siswa seperti pada Tabel 8, juga dianalisis menggunakan teknik gain. Hasil analisis angket karakter tanggung jawab siswa didapatkan gain score, $\langle\mathrm{g}\rangle=0,66$. Peningkatan karakter tanggung jawab tersebut Menurut Hake (1998, p. 65), termasuk dalam kategori "Sedang".

Berdasarkan hasil analisis tersebut, pengembangan karakter disiplin dan tanggung jawab melalui media komik ini secara keseluruhan dapat dikatakan "efektif". Nilai-nilai karakter yang disampaikan melalui tokoh-tokoh dalam komik mempunyai dampak positif terhadap siswa yang membaca komik tersebut. Hal ini sesuai dengan pendapat Asrori (2007, p. 54), yang mengemukakan bahwa anak dalam tahap operasional konkrit akan lebih memahami sesuatu hal yang tampak atau sebagaimana kenyataan yang mereka amati. Siapa yang mereka contoh dan apa yang mereka lihat dapat menjadi dasar pembentukan karakter mereka di masa depan.

Peningkatan karakter melalui media komik ini juga tak lepas dari karakteristik komik yang lain, yakni kekuatan alur cerita. Komik yang dapat dikategorisasikan sebagai buku cerita bergambar ini memang mampu menyampaikan pesan melalui alur cerita. Pesan yang disampaikan oleh komikus dapat mengalir pada diri pembaca tanpa terpengaruh apapun (McCloud, 2001, p. 195). Penggunaan buku cerita bergambar terbukti efektif untuk pendidikan karakter dan keterampilan berbahasa di sekolah seperti penelitian yang dilakukan oleh Faizah (2009, p.249) dalam artikel jurnal cakrawala pendidikan LPPMP UNY 2009.

Selain menggunakan angket, pengembangan nilai karakter disiplin dan tanggung jawab siswa juga dilihat melalui teknik observasi. Berdasarkan hasil observasi seperti tampak pada tabel 9, terdapat peningkatan karakter yang muncul pada siswa. Secara lebih jelas, peningkatan hasil observasi karakter siswa dari pertemuan pertama pertama sampai dengan pertemuan keenam dapat dilihat pada gambar 2 .

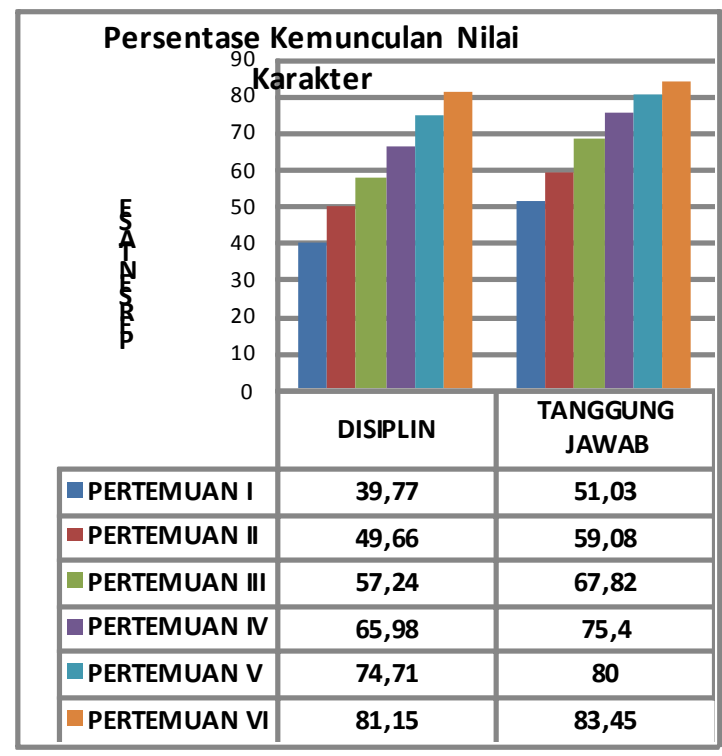

Gambar 2. Diagram Hasil Observasi Karakter Disiplin dan Tanggung Jawab Siswa pada Uji Coba Lapangan

Pembahasan

Pembelajaran tematik-integratif yang dengan menggunakan media komik berbasis karakter, terbukti efektif untuk meningkatkan karakter disiplin dan tanggung jawab. Komik berfungsi sebagai media yang dapat digunakan guru dalam kegiatan belajar mengajar. Penggunaan media komik dengan benar berhasil membuat pembelajaran lebih menyenangkan sehingga tercipta suasana kelas yang lebih efektif dan kondusif. Hal ini disebabkan karena aktivitas guru dalam kelas memberikan peran yang nyata untuk peningkatan kualitas pembelajaran. Kemampuan guru dalam mengggunakan media komik yang dikembangkan berpengaruh terhadap keberhasilan pembelajaran.

Berdasarkan hasil validasi dari ahli media, ahli materi, dan guru SD, seluruh aspek komik yang meliputi aspek anatomi komik, aspek desain dan warna, aspek tampilan menyeluruh, aspek kelayakan materi, aspek keakuratan materi, aspek kemutakhiran materi, aspek kebahasaan, serta aspek karakter, memperoleh penilaian "Sangat baik". Sesuai dengan kualitas media yang telah ditetapkan pada Bab III, bahwa media komik yang dikembangkan dianggap layak jika seluruh aspek yang dinilai mencapai kategori minimal "Baik". Dengan demikian, media komik berbasis karakter untuk pembelajaran tematik-integratif ini telah layak dan siap untuk diuji coba lebih lanjut. 
Tujuan utama dikembangkannya media komik ini adalah untuk merangsang ketertarikan siswa terhadap pembelajaran dan meningkatkan karakter disiplin serta tanggung jawab siswa. Berdasarkan hasil uji coba lapangan, diketahui bahwa penggunaan media komik dalam pembelajaran memberikan pengaruh terhadap peningkatan karakter displin siswa kelas IV SDN Pangen Gudang. Persentase antara skor angket karakter sebelum dan angket sesudah diperoleh karakter disiplin siswa meningkat $18 \%$ dari semula $71,07 \%$ menjadi $89,07 \%$. Berdasarkan analisis menggunakan gain score diperoleh $\langle\mathrm{g}\rangle=0,62$. Menurut Hake (1998, p. 65) peningkatan karakter disiplin tersebut termasuk dalam kategori "sedang", artinya telah terjadi peningkatan karakter disiplin siswa kelas IV SDN Pangen Gudang. Media komik yang dikembangkan dapat membantu meningkatkan karakter disiplin siswa kelas IV SDN Pangen Gudang dengan tingkat kenaikan yang "sedang".

Berdasarkan hasil uji coba lapangan juga dapat diketahui bahwa penggunaan media komik dalam pembelajaran memberikan pengaruh terhadap peningkatan karakter tanggung jawab siswa kelas IV SDN Pangen Gudang. Persentase antara skor pretest dan posttest karakter tanggung jawab siswa meningkat $18,86 \%$ dari semula $71,59 \%$ menjadi $90,45 \%$. Berdasarkan analisis menggunakan gain score diperoleh $\langle\mathrm{g}\rangle$ = 0,66. Menurut Hake (1998: 65) peningkatan karakter tanggung jawab tersebut termasuk dalam kategori "sedang", artinya telah terjadi peningkatan karakter tanggung jawab pada siswa kelas IV SDN Pangen Gudang. Media komik yang dikembangkan dapat membantu meningkatkan karakter tanggung jawab siswa kelas IV SDN Pangen Gudang dengan tingkat kenaikan yang "sedang".

Selain menggunakan angket, efektivitas penggunaan media komik terhadap peningkatan karakter disiplin dan tanggung jawab siswa juga dilihat melalui teknik observasi. Hasil observasi seperti tampak pada tabel 9, terdapat peningkatan karakter yang muncul pada siswa. Berdasarkan visualisasi dari gambar 2, persentase karakter disiplin dan tanggung jawab mengalami peningkatan dari observasi awal sampai dengan pertemuan keenam. Hasil ini sudah sejalan dengan peningkatan yang di peroleh dari hasil angket, sehingga dapat dikatakan bahwa media komik "efektif" digunakan sebagai salah satu alat pendidikan karakter.
Berdasarkan hasil kajian akhir tersebut dapat diperoleh informasi bahwa kualitas media komik yang dikembangkan telah layak digunakan dalam pembelajaran matematika kelas IV SD. Dengan demikian, media komik berbasis karakter dapat diimplementasikan sesuai tujuan yang hendak dicapai yaitu untuk meningkatkan karakter disiplin dan tanggung jawab siswa kelas IV SD.

\section{Simpulan dan Saran}

\section{Simpulan}

Berdasarkan hasil penelitian dan pembahasan tentang pengembangan media komik dapat disimpulkan berikut ini (1) Telah dapat dikembangkan media komik berbasis karakter untuk pembelajaran tematik-integratif dengan tema "Makananku Sehat dan Bergizi" yang layak untuk siswa kelas IV SD. Berdasarkan hasil validasi dari ahli media, ahli materi, dan guru SD, seluruh aspek komik yang meliputi aspek anatomi komik, aspek desain dan warna, aspek tampilan menyeluruh, aspek kelayakan materi, aspek keakuratan materi, aspek kemutakhiran materi, aspek kebahasaan, serta aspek karakter, memperoleh penilaian "Sangat baik". Hal tersebut membuktikan bahwa produk pengembangan berupa media komik berbasis karakter valid dan layak untuk digunakan dalam pembelajaran di kelas IV SD. (2) Media komik berbasis karakter yang dikembangkan, terbukti efektif meningkatkan karakter disiplin dan tanggung jawab siswa kelas IV SDN Pangen Gudang Purworejo. Keefektifan media komik terlihat dari data yang diperoleh melalui lembar angket dan lembar observasi karakter siswa. Hasil analisis angket karakter disiplin siswa didapatkan gain score, $\langle\mathrm{g}\rangle=0,62$, sedangkan hasil analisis angket karakter tanggung jawab siswa didapatkan gain score, $\langle\mathrm{g}\rangle=0,66$. Hal ini berarti terjadi peningkatan karakter dengan kategori "Sedang". Selain menggunakan angket, peningkatan karakter disiplin dan tanggung jawab siswa juga diamati melalui teknik observasi yang menunjukkan persentase karakter disiplin dan tanggung jawab mengalami peningkatan dari observasi pertemuan pertama sampai dengan pertemuan keenam.

Saran

Saran pemanfaatan, diseminasi, dan pengembangan lebih lanjut, disarankan kepada guru untuk menggunakan media komik ini sebagai media pembelajaran tematik-integratif 
di kelas IV SD, sebagai variasi media pembelajaran ataupun sebagai bahan ajar mandiri siswa. Media komik yang dikembangkan ini masih terbatas pada tema "Makananku Sehat dan Bergizi". Oleh karena itu untuk pengembangan lebih lanjut perlu dikembangkan media komik pembelajaran pada tema yang lain. Dalam rangka pemanfaatan secara luas, produk pengembangan berupa media komik berbasis karakter ini dapat disosialisasikan kepada pendidik dan beberapa sekolah lain.

\section{Daftar Pustaka}

Azzet, A. M. (2011). Urgensi pendidikan karakter di Indonesia. Yogyakarta: ArRuzz Media.

Borg, W. \& Gall, M. (1983). Educational research: An introduction 4th edition.. New York. Longman Inc.

Depdiknas. (2008). Panduan pengembangan bahan ajar. Jakarta: Pusat Penelitian dan Pengembangan.

Hake, R. R. (1998). Intercative-engagement versus traditional method: A sixthousand-student survey of mechanics test data for introductory physics courses. American Association of Physics Teachers, 66, pp.64-74.

Humphrey, M. (2005). Living the hero's quest: Character building through action research. London: Libraries Unlimited.
Kemdikbud. (2012). Dokumen Kurikulum 2013. Jakarta: Kemdikbud.

Kesuma, D., Trianta, C., \& Permana, J. (2012). Pendidikan karakter: Kajian teori dan praktik di sekolah. Bandung: PT Remaja Rosdakarya.

Maharsi, I. (2010). Komik dunia kreatif tanpa batas. Yogyakarta: Kata Buku.

Newby, et. al. (2000). Instructional technology for teaching and learning. Upper Saddle River: Pearson Education, Inc.

Orey, M., McClendon, V. J., \& Branch, R. M. (2006). Educational media and technology yearbook. Santa Barbara: Libraries Unlimited.

Rohman, A. (2009). Memahami pendidikan dan ilmu pendidikan. Yogyakarta: LaksBang Mediatama.

Samani, M. (2013). Konsep dan model pendidikan karakter. Bandung: PT Remaja Rosdakarya.

Saptono. (2011). Dimensi-dimensi pendidikan karakter. Salatiga: Esensi.

Sasongko. (2013). Panen duit dari kartun, komik, ilustrasi. Klaten: Pustaka Wasilah

Sudjana, N., \& Rivai, A. (2010). Media pengajaran. Bandung: Penerbit Sinar Baru Algensindo. 